\title{
DESAIN TATA LETAK SIRKUIT TERPADU DALAM PERSPEKTIF PERBANDINGAN HUKUM INTEREN
}

\author{
Sudjana \\ email: sdjana@yahoo.com
}

\begin{abstract}
The author discusses the legal protection of integrated circuit layout design as provided by Law $32 / 2000$ and compares it with how the government regulates and protect other sorts of intellectual property rights (copyright, trademarks, patents, etc.). The purpose of this comparison is to reveal shortcomings as well as the strength of each different regulations. This study reveals that Law 32/2000 as compared to other IPR protections has yet to provide legal protection of inventor's moral rights, priority rights as well as temporary decision. At the same time, all regulations cannot be fully implemented due to the lack of or insufficient implementing regulations.
\end{abstract}

Keywords:

Integrated Circuit Layout Design, internal legal comparison.

\begin{abstract}
Abstrak
Penulis membandingkan pengaturan Desain Tata Letak Sirkuit Terpadu, di dalam UU No. 32/2000, dengan pengaturan bentuk-bentuk hak atas kekayaan intelektual lainnya. Tujuannya adalah mengidentifikasi kelemahan dan kelebihan pengaturannya. Penelitian menunjukkan bahwa UU No. $32 / 2000$, belum mengatur cukup hak moral pencipta, hak prioritas dan penetapan sementara. Pada saat sama ditemukan pula bahwa semua peraturan tentang kekayaan intelektual terhambat karena ketiadaan atau kurangnya peraturan pelaksana.
\end{abstract}

Kata Kunci: Desain Tata Letak Sirkuit Terpadu, Perbandingan Hukum Interen.

\section{Pendahuluan}

Untuk memajukan industri yang mampu bersaing dalam lingkup perdagangan nasional dan internasional perlu diciptakan iklim yang mendorong kreasi dan inovasi masyarakat di bidang Desain Tata Letak Sirkuit Terpadu (selanjutnya disebut DTLST) sebagai bagian dari sistem Kekayaan Intelektual (selanjutnya disebut KI). ${ }^{1}$ Hal ini mengingat bahwa Indonesia telah meratifikasi Agreement Establishing the World Trade Organization (Persetujuan Pembentukan Organisasi Perdagangan Dunia) yang mencakup Agreement on Trade Related Aspects of Intellectual Property Rights (Persetujuan TRIPs) dengan UndangUndang (selanjutnya disebut UU) Nomor 7 Tahun 1994 sehingga perlu diatur

\footnotetext{
${ }^{1}$ Bagian Menimbang huruf a UU No 32 Tahun 2000 Tentang DTLST.
} 
ketentuan mengenai DTLST. ${ }^{2}$ Namun demikian, perlindungan terhadap kreasi dan inovasi tidak hanya diberikan oleh DTLST tetapi juga melalui KI lainnya. Oleh karena itu perlu untuk melakukan analisis perbandingan secara interen dalam arti melakukan perbandingan terhadap DTLST dengan KI lainnya untuk menemukan persamaan dan perbedaan tentang ketentuan-ketentuan apa saja diatur, sekaligus kelemahan dan kelebihannya. Berdasarkan hal itu, maka rumusan permasalahan dalam kajian ini adalah "Bagaimana perlindungan DTLST dalam Perspektif Perbandingan Hukum Intern."?

Untuk mengkaji permasalahan tersebut digunakan metode penelitian melalui pendekatan yuridis komparatif (perbandingan DTLST dengan jenis KI lainnya), dan analisis data bersifat normatif kualitatif (bertitik tolak dari perundang-undang, tidak menggunakan rumus statistik), serta teknik pengumpulan data melalui studi kepustakaan untuk mengkaji bahan hukum primer (perundang-undangan), bahan hukum sekunder (pendapat para ahli), dan bahan hukum tersier (internet) yang bertujuan untuk mendapatkan informasi langsung berkenaan dengan penelitian. ${ }^{3}$

\section{Pembahasan}

\section{Kajian Teori}

Perbandingan hukum (rechtsvegelijking, Rechtsvergeleichung) merupakan cabang ilmu karena perbandingan hukum memenuhi syarat-syarat sebagai ilmu, yaitu pengetahuan, sistematis, rasional dan dapat diuji kebenarannya. ${ }^{4}$ Sedangkan, perbandingan hukum sebagai metode, yaitu membandingkan hukum yang satu dengan hukum lainnya. Perbandingan hukum memberikan hasil baru yg tidak dapat ditemui jika hanya mempelajari cabang-cabang hukum interen. ${ }^{5}$ Sudikno dengan mengutip van Apeldoorn menjelaskan bahwa perbandingan hukum adalah

2 Id, Bagian Menimbang huruf $b$.

3 Bandingkan dengan Soerjono Soekanto dan Sri Mamudji, Penelitian Hukum Normatif: Suatu Tinjauan Singkat, PT RajaGrafindo Persada, Jakarta ,2004, hlm., 13.

4 Soerjono Soekanto, Sosiologi Suatu Pengantar, PT RajaGrafindo Persada, Jakarta, 1998, hlm., 6-8.

5 http://elearning.upnjatim.ac.id/courses/HKB7024ff34/document/pengenalan_perbandingan_ hukum.pptx?cidReq=HKB702429e2. Diakses 15 Agustus 2016, pukul 21.00 WIB. 
mencari perbedaan-perbedaan serta persamaan-persamaan dengan memberi penjelasan dan meneliti berfungsinya hukum yang mempengaruhinya. Penjelasan dari perbandingan tersebut hanya dapat diketahui dalam sejarah hukumnya, sehingga perbandingan hukum yang ilmiah memerlukan perbandingan sejarah hukum. ${ }^{6}$ Lebih lanjut Sudikno menjelaskan: "konkritnya dalam memperbandingkan hukum yang diteliti adalah hukum yang hidup (the law in action), jadi bukan semata-mata hanya hukum yang dimuat dalam peraturan perundang-undangan atau yang diuraikan dalam buku-buku saja (the law in the books), tetapi juga penafsiran undang-undang atau penemuan hukum dalam peradilan dan kepustakaan. Jadi yang diperbandingkan adalah hukum sebagaimana nyata-nyata berfungsi di dalam masyarakat di tempat tertentu. Perlu diteliti fungsi pemecahan yuridis dalam praktiknya serta adanya pengaruh faktorfaktor asing, cara pendekatan hukum semacam ini dengan mempelajari hukum yang hidup, dan nyata-nyata berlaku disebut "functional approach", suatu pendekatan hukum dengan memperhatikan berlakunya hukum secara fungsional.

Dalam memperbandingkan hukum dikenal dua cara, yaitu memperbandingkan secara makro dan mikro. Perbandingan secara makro adalah cara memperbandingkan masalah-masalah hukum pada umumnya sedangkan Perbandingan secara mikro adalah cara memperbandingkan masalah-masalah hukum tertentu. Hukum yang telah diketahui yang akan diperbandingkan disebut "comparatum", sedangkan hukum yang akan diperbandingkan dengan yang telah diketahui disebut "comparandum." Setelah diketahui dua hukum itu perlu ditetapkan apa yang akan diperbandingkan yang disebut "tertium comparatum."7 Perbandingkan hukum sebagai metode dapat dilakukan secara interen, yaitu mengkaji peraturan atau ketentuan hukum di dalam suatu negara, dan secara eksteren, yakni membandingkan hukum yang berlaku di suatu negara dengan negara lainnya.

${ }^{6}$ Van Apeldoorn, sebagaimana dikutip oleh Sudikno dalam, http://sudiknoartikel. blogspot.co.id/2012/04/perbandingan-hukum.html. Diakses 18 Agustus 2016, pukul 22.00 WIB. 7 Id. 
Secara konvensional, KI dibagi menjadi 2 bagian yang seluruhnya terdapat 7 (tujuh) jenis KI yaitu (1) Hak Cipta dan Hak terkait, serta (2) Kekayaan Perindustrian, yang mencakup Paten, Merek, Rahasia Dagang, Desain Industri, Perlindungan Varietas Tanaman dan DTLST. Konvensi internasional yang berkaitan dengan perlindungan Kekayaan Perindustrian adalah International Convention for the Protection of Industrial Property Right yang dikenal dengan Konvensi Paris (Paris Convention) yang ditandatangani di Paris pada tanggal 20 Maret 1883, kemudian direvisi pada Tanggal 14 Juli 1967 di Stockholm dan telah diubah pada tanggal 28 September 1979. Konvensi Paris tahun 1967 memuat prinsip-prinsip dasar yang berkaitan dengan hak, kewajiban dan larangan bagi negara-negara dalam melaksanakan Kekayaan Perindustrian. Namun Konvensi Paris pada prinsipnya mengatur secara umum perlindungan Kekayaan Perindustrian, yang berfungsi sebagai payung bagi perlindungan KI di seluruh dunia, ${ }^{8}$ karena itu terhadap DTLST sebagai bagian dari Kekayaan Perindustrian, prinsip-prinsip dari Konvensi Paris dapat diberlakukan meskipun tidak secara tegas mengaturnya. ${ }^{9}$

Istilah DTLST berasal dari istilah Layout Design (Topographies) dan Integrated Circuit, yang perumusannya menurut Washington Treaty adalah sebagai berikut: 10

Sirkuit Terpadu berarti suatu hasil produksi dalam bentuk terakhir atau setengah jadi yang di dalamnya terdapat berbagai elemen dan sekurang-kurangnya 1 (satu) dari elemen tersebut adalah elemen aktif yang sebagian atau seluruhnya saling berkaitan serta dibentuk secara terpadu di dalam sebuah semikonduktor. ${ }^{11}$

8 Rachmadi Usman, Hukum Hak atas Kekayaan Intelektual: Perlindungan dan Dimensi Hukumnya di Indonesia, Alumni, Bandung, 2003, hlm., 13.

9 Article 1 [Establishment of the Union; Scope of Industrial Property] paragraph (1) The countries to which this Convention applies constitute a Union for the protection of industrial property.

${ }^{10}$ Article 2 of Treaty on Intellectual Property in Respect of Integrated Circuits.

11 "Integrated circuit means a product, in its final forma or an intermediate form, in which the elements, at least one of which is in an active element, and some or all of the interconnections are integrally formed in and / or on a piece of material and which is intended to perform an electronic function." 
Kemudian, Layout Design diartikan sebagai berikut: ${ }^{12}$

"Kreasi berupa rancangan peletakan 3 (tiga) dimensi dari berbagai elemen, sekurang-kurangnya 1 (satu) dari elemen tersebut adalah elemen aktif serta sebagian atau semua interkoneksi dalam suatu Sirkut Terpadu dan peletakan 3 (tiga ) dimensi tersebut dimaksudkan untuk persiapan pemuatan Sirkuit Terpadu).

Pengertian DTLST menurut: United States of America, Semiconductor Chip Protection Act of 1984 (Title III of Public Law 98-620 of November 8, 1984) adalah:

(Suatu produk chip semikonduktor adalah bentuk akhir atau tingkatan lanjutan dari setiap produk yang memiliki dua atau lebih lapisan metalik, penyekat, atau bahan semikonduktor, lapisan atau bagian sebaliknya, atau sketsa atau yang dapat dilepaskan dari sebaliknya, sekeping bahan semikonduktor sesuai dengan pola yang ditetapkan sebelumnya dimaksudkan untuk melakukan fungsi kontak elektronik).

Kemudian a circuit layout shall means a layout of circuitry elements and lead wires connecting such elements in a semiconductor integrated circuit (Suatu tata letak kontak berarti suatu tata letak bahan-bahan kontak dan petunjuk hubungan kabel-kabel, bahan-bahan demikian di dalam suatu kontak terpadu semikonduktor). ${ }^{13}$

Definisi menurut Pasal 1 butir 1 UU. No.32 Tahun 2000 Tentang DTLST mengacu kepada Perjanjian Washington (IPIC Treaty), yaitu:

"Sirkuit Terpadu adalah suatu produk dalam bentuk jadi atau setengah jadi, yang di dalamnya terdapat berbagai elemen dan sekurang-kurangnya satu dari elemen tersebut adalah elemen aktif, yang sebagian atau seluruhnya saling berkaitan serta dibentuk secara terpadu di dalam sebuah bahan semi konduktor yang dimaksudkan untuk menghasilkan fungsi elektronik."

\footnotetext{
12 "a semiconductor chip product is the final or intermediate form of any product " having two or more layers of metallic, insulating, or semiconductor material, deposited or otherwise placed on, or etched away or otherwise removed from, a piece of semiconductor material in accordance with a predetermined pattern intended to perform electronic circuitry function."

13 Badan Pembinaan Hukum Nasional-Depkeh RI, Naskah Akademis Peraturan Perundangundangan tentang RUU Perlindungan Integrated Circuits, 1994-1995, hlm., 9-10.
} 
Selanjutnya Pasal 1 butir 2 UU No. 32 Tahun 2000 menjelaskan:

"DTLST adalah kreasi berupa rancangan peletakan tiga dimensi dari berbagai elemen aktif, serta sebagian atau semua interkoneksi dalam suatu Sirkuit Terpadu dan peletakan tiga dimensi tersebut dimaksudkan untuk persiapan Sirkuit Terpadu."

Paingot Rambe Manalu menjelaskan bahwa ketika Layout Design diciptakan (belum berbentuk Integrated Circuit), maka sesungguhnya termasuk Hak Cipta, namun setelah proses mentransfer dari wujud desain menjadi Chip (Micro-Chip) tidak lagi hak cipta. Karena keunikan itu, maka tepat peraturannya dilakukan tersendiri. ${ }^{14}$

\section{Perlindungan Tata Letak Sirkuit Terpadu}

Pengaturan DTLST dalam Perjanjian TRIPs-WTO terdapat pada Pasal 35 s/d Pasal 38.15 Pasal 35 Perjanjian TRIPs ini mengatur hubungannya dengan Washington Treaty 1989 (Treaty on Intellectual Property in Respect of Integrated Circuit/IPIC) yang menjelaskan bahwa negara-negara anggota WTO sepakat untuk memberikan perlindungan terhadap Desain Tata Letak (Topografi) Sirkuit Terpadu sesuai dengan Ketentuan-ketentuan Pasal 2 s/d Pasal 7 IPIC kecuali Pasal 6 Ayat (3), Pasal 12 dan Pasal 16 Ayat (3) IPIC. Sebagai akibat dari ketentuan TRIPs, Perjanjian Washington menjadi bertambah penting, sehingga perlindungan terhadap DTLST mencakup juga ketentuan yang diatur dalam Perjanjian Washington. ${ }^{16}$

\footnotetext{
${ }^{14}$ Paingot Rambe Manalu, Hukum Dagang International, Pengaruh Globalisasi Ekonomi Terhadap Hukum Nasional, khususnya Hukum Hak Atas Kekayaan Intelektual, CV Novindo Pustaka Mandiri, Jakarta, 2000, hlm., 206.

${ }^{15}$ Article 35 Relation to IPIC Treaty:

"Member agree to provide protection to the Layout-Design (Topo-graphies) of Integrated Circuit (hereinafter refered to as "Layout-Design") in accordance with Articlec 2-7 (other than paragraph 3 of Article 6). Article 12 and paragraph 3 of Article 16 of the Treaty on Intellectual Property in Respect of Integrated Circuit and, in addition, to comply with the following provisions." Bandingkan dengan Sudargo Gautama dan Rizawanto Winata, Undang-Undang Desain Tata Letak Sirkuit Terpadu, Citra Aditya Bakti, Bandung, 2002, hlm., 13-15, 25, Lihat juga Supra no 8, hlm., 462-465.

${ }^{16}$ Sudargo Gautama dan Rizawanto Winata, Id, hlm 13-26.
} 
Pasal 36 Perjanjian TRIPs-WTO ${ }^{17}$ mengatur mengenai ruang lingkup perlindungan hukum untuk DTLST. Menurut Pasal ini, dengan memperhatikan ketentuan-ketentuan dalam Pasal 37 Ayat (1), Negara-negara anggota WTO berkewajiban untuk menetapkan sebagai pelanggaran hukum setiap tindakantindakan di bawah ini apabila dilakukan tanpa izin dari pemegang hak DTLST, yaitu mengimpor, menjual, atau mendistribusikan untuk tujuan komersial Desain Tata Letak yang dilindungi atau barang yang di dalamnya terdapat Sirkuit Terpadu, sepanjang barang tersebut diperbanyak secara melawan hukum. Berdasarkan ketentuan Pasal 36 Perjanjian TRIPs-WTO tersebut diuraikan mengenai perbuatan-perbuatan yang menjadi ruang lingkup perlindungan DTLST.

Pasal 37 Perjanjian TRIPs-WTO menyatakan:18 tindakan-tindakan yang dianggap bukan pelanggaran hukum dan tindakan lainnya yang tidak memerlukan izin dari pemegang hak DTLST. Pasal 37 ini menyatakan bahwa dengan tidak mengurangi ketentuan seperti yang tercantum dalam Pasal 36, tidak satupun negara-negara anggota WTO menetapkan sebagai pelanggaran hukum suatu perbuatan yang disebutkan pada Pasal 36.19

${ }^{17}$ Article 36 Scope of the Protection: "Subject to the provisions of paragraph 1 of Article 37 below, members shall consider unlawful the following acts if performed without yhe authorization of the right holder: importing, selling, or otherwise distributing for commercial purposes a protected Layout- Design, an Integrated Circuit in which a protected Layout- Design is incorporated, or an article incorporating such an integrated circuit only insofar as it continues to contain an unlawfully reproduced Lay out-Design. "

${ }^{18}$ Article 37 Acts not requiring the Authorization of the Right Holder: 1. Notwithstanding Article 36 above, no member shall consider unlawful the performance of any of the acts referred to in that Article in Respect of Integrated Circuit incorporating an unlawfully reproduced Layout-Design or any article incorporating such an Integrated Circuit where the person performing or ordering such acts did not know and had no reasonable ground to know, when acquiring the integrated circuit or article incorporating such an Integrated Circuit, that it incorporated an unlawfully reproduced Layout-Design. Members shall provide that, after the time that such persons has received sufficient notice that the Layout-Design was unlawfully reproduced, he may perform any of the acts with respect to the stock on hand or ordered before such time, but shall be liable to pay to the right holder a sum equivalent to a reasonable royalty such as would be payable under a freely negotiated license in respect of such a Layout-Design. 2. The conditions set out in sub-paragraphs ( $a)-(k)$ of Article 31 above shall apply mutatis mutandis in the event of any non-voluntary licensing af a Layout-Design or of its use by or for the government without the authorization of the right holder.

${ }^{19}$ yaitu berkenaan dengan Sirkuit Terpadu yang memuat reproduksi Desain Tata Letak secara melawan hukum atau suatu produk yang memuat Sirkuit Terpadu itu apabila orang yang melakukan perbuatan atau memerintahkan dilakukannya perbuatan tersebut tidak mengetahui dan tidak mempunyai alasan yang wajar untuk mengetahui ketika memperoleh Sirkuit Terpadu 
Berdasarkan ketentuan Pasal 37 Ayat (1) Perjanjian TRIPs-WTO, tidak dianggap sebagai perbuatan melawan hukum terhadap DTLST, apabila tidak mengetahui atau tidak sewajarnya mengetahui bahwa DTLST tersebut diproduksi secara melawan hukum. Kemudian Pasal 37 Ayat (2) Perjanjian TRIPs-WTO: segala persyaratan yang tercantum dalam Pasal 31 sub a sampai dengan sub $\mathrm{k}$ berlaku juga apabila terjadi lisensi secara paksa (wajib) atau penggunaan oleh atau untuk pemerintah tanpa izin dari pemegang hak Desain Tata Letak. Dalam hal ini dipakai ketentuan tentang Paten seperti yang diatur dalam Pasal 31 Perjanjian TRIPs-WTO yaitu Negara anggota membolehkan adanya lisensi paksa tentang Paten tanpa Perjanjian Pemegang hak, termasuk juga pemakaian oleh Pemerintah atau pihak ketiga yang disetujui oleh Pemerintah. Adapun Pasal 31 sub a sampai dengan sub k Perjanjian TRIPs-WTO mengatur tentang penggunaan hak tanpa perlu otorisasi dari pemegang hak. Hal ini berkaitan dengan persetujuan untuk pemakaian akan diperhatian secara individual (tidak ada generalisasi), meskipun hal itu tergantung pada permasalahan yang ada. Kemudian pemakaian tanpa persetujuan pemegang paten hanya dibolehkan apabila sebelumnya sudah berusaha untuk memperoleh persetujuan dari pemegang hak, ketentuan ini dapat dikesampingkan apabila ada keadaan darurat nasional. Selanjutnya pemberian hak tersebut ditujukan bagi pasaran domestik Negara anggota WTO yang telah membolehkan pemakaian DTLST, namun tidak mengurangi perlindungan yang cukup bagi pihak yang diberi otorisasi serta akan dihentikan apabila keadaan lisensi paksa sudah tidak ada lagi. Selanjutnya, pemegang hak akan diberi ganti rugi yang layak dalam setiap hak dengan memperhatikan nilai ekonomis dari pemberian otorisasi ini. Nilai hukum dari tiap putusan berkenaan dengan otorisasi

atau produk yang memuat Sirkuit Terpadu itu, bahwa Sirkuit Terpadu atau produk yang berisi Desain Tata Letak yang diproduksi secara melawan hukum. Negara-negara anggota WTO akan mengatur bahwa setelah berakhirnya jangka waktu untuk menyampaikan pemberitahuan yang cukup kepada orang yang bersangkutan bahwa Desain Tata Letak hasil reproduksi secara melawan hukum, orang tersebut dapat melanjutkan kegiatannya sepanjang terbatas pada penggunaan persediaan yang sudah ada atau barang telah dipesan sebelumnya, namun tetap mempunyai kewajiban untuk memberikan imbalan kepada pemegang hak yang sebenarnya untuk jumlah yang setara dengan royalty yang harus dibayar secara wajar dalam suatu lisensi yang diperjanjikan secara bebas (sukarela). 
tunduk kepada peninjauan kembali dan setiap putusan berkenaan dengan ganti rugi dari KI yang bersangkutan harus ditinjau kembali secara legal oleh instansi yang lebih tinggi di dalam negara anggota yang bersangkutan. Para negara anggota tidak perlu memperhatikan persyaratan tentang "sudah berusaha untuk memperoleh persetujuan" dan "pemakaian untuk pasaran domestik" apabila pemakaian tersebut telah dibolehkan setelah proses hukum atau administratif yang menyatakan telah terjadi monopoli (anti competitive). ${ }^{20}$

Pasal 38 Perjanjian TRIPs ${ }^{21}$ mengatur mengenai jangka waktu perlindungan (Term of Protection) DTLST. Pasal 38 Ayat (1) Perjanjian TRIPs menyatakan,

"Negara-negara anggota WTO yang mewajibkan pendaftaran sebagai syarat untuk diberikannya perlindungan, maka jangka waktu perlindungan hukum terhadap Desain Tata Letak ini berlangsung paling lama 10 Tahun terhitung sejak saat pengajuan permohonan pendaftaran atau sejak pemanfaatan (penggunaan) secara komersial untuk pertama kalinya, digunakan di seluruh dunia".

Kemudian Pasal 38 Ayat (2):

"Dalam hal negara-negara anggota WTO tidak mewajibkan pendaftaran sebagai syarat untuk memperoleh perlindungan hukum, maka DTLST ini akan diberi perlindungan tidak kurang dari 10 Tahun sejak saat digunakan secara komersial diseluruh dunia.

Selanjutnya, menurut Pasal 38 Ayat (3):

Sesuai dengan ketentuan yang tercantum dalam Pasal 38 Ayat (1) dan Ayat (2) negara-negara anggota WTO dapat menetapkan bahwa

\footnotetext{
${ }^{20}$ Selengkapnya lihat Pasal 31 sub a sampai dengan sub k Perjanjian TRIPs-WTO.

${ }^{21}$ Ketentuan Pasal 38 Perjanjian TRIPs-WTO berbunyi: (1). In Members requiring registration as a condition of protection, the term of protection of Layout-Designs shall not end before the expiration of a period of ten years counted from the date of filing an application for registration or from the first commercial exploitation wherever in the world it occurs; (2). In Members not requiring registration as a condition for protection. Layout-Design shall be protected for a term of no less than ten years from the date of the first commercial exploitation wherever in the world it occurs; (3). Notwithstanding paragraphs 1 and 2 above, a Member may provide that protection shall lapse fifteen years after the creation of layout-design.
} 
perlindungan hukum berakhir setelah lewat waktu 15 Tahun sejak Desain Tata Letak yang bersangkutan diciptakan.

Dengan demikian, Pasal 38 Perjanjian TRIPs memberikan kebebasan kepada setiap negara anggota WTO untuk menentukan sendiri jangka waktu perlindungan hukumnya dikaitkan dengan ada tidaknya persyaratan pendaftaran sebagai cara untuk memperoleh hak.

Ketentuan tentang Subyek DTLST diatur dalam Pasal 5 dan Pasal 6 UU. No 32 Tahun 2000. Pada dasarnya yang menjadi subyek DTLST adalah pendesain, yaitu orang atau mereka yang menghasilkan rancangan DTLST dan mereka yang menerima hak DTLST dari pendesain. Dengan demikian ketentuan Pasal 5 Ayat (1) UU No. 32 Tahun 2000 ini secara tegas mengatakan bahwa Pendesain atau yang menerima hak DTLST melalui pewarisan, hibah, wasiat, perjanjian tertulis atau sebab-sebab lain yang dibenarkan oleh peraturan perundang-undangan yang berhak mendapat perlindungan hukum. Sedangkan Pasal 5 Ayat (2) UU No. 32 Tahun 2000 menjelaskan tentang hak milik bersama atas DTLST yang dihasilkan oleh beberapa orang yang secara bersama menghasilkan DTLST. Hal ini berarti kepada mereka akan diberikan hak tersebut, namun mereka dapat memperjanjikan lain, ${ }^{22}$ yaitu hanya salah satu pihak saja yang memperoleh hak DTLST sedangkan pihak yang lainnya tidak diberikan. Selanjutnya, dalam kaitannya dengan hubungan dinas atau hubungan kerja, ketentuan Pasal 6 Ayat (1) UU No. 32 Tahun 2000 secara tegas mengatakan bahwa kecuali diperjanjikan lain antara kedua pihak, yang dianggap sebagai pemegang hak DTLST adalah instansi pemerintah apabila desain tersebut dikerjakan dalam hubungan dinas, namun pemilik hak DTLST tetap berada pada pendesainnya. Kemudian sesuai Pasal 6 Ayat (2) UU No. 32 Tahun 2000, ketentuan itu berlaku juga apabila hak DTLST dibuat orang lain berdasarkan pesanan yang dilakukan dalam hubungan dinas, misalnya dari instansi pemerintah, tetap dipegang oleh instansi pemerintah tersebut sebagai pemesan dengan tidak mengurangi hak pendesain untuk

22 Sesuai dengan Asas Kebebasan Berkontrak sebagaimana diatur dalam Pasal 1338 Ayat (1) KUHPerdata. 
menuntut haknya apabila DTLST digunakan untuk kepentingan di luar hubungan dinas. Sedangkan apabila DTLST dibuat dalam hubungan kerja atau berdasarkan pesanan, orang yang membuat desain dianggap sebagai pendesain dan pemegang hak, kecuali diperjanjikan lain. Kemudian Ketentuan Pasal 7 UU No. 32 Tahun $2000^{23}$ mengandung makna bahwa DTLST bersifat pribadi dan menyatu dengan pendesainnya, sehingga hak moralnya (moral right), yaitu hak untuk mencantumkan nama pendesain tetap melekat meskipun sudah dialihkan kepada pihak lain. Ketentuan hak moral erat kaitan dengan Ajaran Hukum Alam dengan tokohnya Grotius yang mengatakan bahwa kepemilikan seseorang harus dilindungi. Dengan demikian yang dapat beralih atau dialihkan adalah hak ekonomi, yaitu hak untuk menikmati atau memperoleh keuntungan secara ekonomi dari pemegang hak atau pemilik DTLST, tetapi pemikiran tersebut berbeda dengan Pandangan John Locke dan Hegel. Locke berpendapat tentang proses manusia mendapat pengetahuan (KI) memiliki dua implikasi penting. ${ }^{24}$ Pertama, munculnya anggapan bahwa seluruh pengetahuan manusia berasal dari pengalaman, dan tiadanya pengetahuan secara apriori (sebelum pengalaman) sebagaimana yang dikatakan Descartes. Kedua, semua hal yang manusia ketahui melalui pengalaman, bukanlah obyek atau benda pada dirinya sendiri, melainkan hanya kesan-kesan indrawi dari hal itu yang diterima oleh panca indra manusia. Sedangkan menurut Hegel yang dikenal dengan "dialektika" adalah dua hal yang dipertentangkan lalu didamaikan, atau biasa dikenal dengan tesis (pengiyaan), antitesis (pengingkaran) dan sintesis (kesatuan kontradiksi). Pengiyaan harus berupa konsep pengertian yang empiris indrawi. Kontradiksi merupakan motor dialektika (jalan menuju kebenaran) maka kontradiksi harus mampu membuat

\footnotetext{
${ }^{23}$ Lihat Pasal 7 UU No. 32 Tahun 2000.

${ }^{24}$ Franz Magnis-Suseno, Filsafat sebagai Ilmu Kritis, Kanisius, Yogyakarta, 1992, hlm. 73-74 tersedia dalam https://id.wikipedia.org/wiki/John_Locke. Diakses 25 November 2016, pukul 20.00 WIB.
} 
konsep yang bertahan dan saling mengevaluasi serta melengkapi dua konsep pengertian yang saling berlawanan agar tercipta konsep baru yang lebih ideal. ${ }^{25}$

Pengaturan hak ini sesuai dengan tujuan hukum yaitu keadilan (kumutatif) sebagaimana dikemukakan oleh Aristoteles, keadilan (kumutatif), yaitu memberikan keadilan berdasarkan jasa yang telah diberikan dan Recovery Theory, ${ }^{26}$ serta sejalan dengan pendapat Bentham bahwa tujuan hukum (pengaturan hak ekonomi dalam) untuk memperoleh kemanfaatan atau kegunaan yang dijabarkan melalui Utility Theory yang berbunyi "the greatest happiness for the greatest number" (kebahagiaan terbanyak untuk kelompok terbesar). Namun untuk Indonesia, ajaran Bentham tersebut perlu dikoreksi karena tidak sesuai dengan Pancasila (sila 5) dan konsep Negara Kesejahteraan bahwa keadilan dalam mencapai kebahagian atau kesejahteraan bukan untuk kelompok terbesar tetapi seluruh rakyat Indonesia.

Ruang Lingkup DTLST sebagaimana diatur dalam Pasal 8 UU No. 32 Tahun 2000 adalah memberikan hak eksklusif kepada pemegang hak untuk selama waktu tertentu, baik melaksanakan sendiri atau memberikan izin kepada pihak lain untuk melaksanakan hak DTLST yang dilindungi. Dalam kaitan dengan sifat eksklusif, Hilary Pearson dan Clifford Miller berpendapat: ${ }^{27}$

"The term property refers to something capable of ownership. Ownership basically means right to posses, use and dispose of property to the exclusion of others. If you own land you have the exclusive legal right to keep out everyone except those you choose to invite to visit. If you own a car you have the exclusive legal right to stop some one else driving it without your permission. If you own copyright in a copyright work you have several legal rights, including the exclusive right to prevent anyone copying the work."

\footnotetext{
25 https://id.wikipedia.org/wiki/Georg_Wilhelm_Friedrich_Hegel. Diakses 15 Desember 2016, pukul 21.00 WIB.

${ }^{26}$ Recovery Theory yang mengatakan bahwa seseorang berhak atas perlindungan untuk memperoleh kembali sesuatu yang telah dikeluarkannya (dalam hal ini Pemegang/pendesain DTLST telah mengeluarkan biaya, waktu, tenaga dan pikiran)

${ }^{27}$ Hilary Pearson dan Clifford Miller, Commercial Exploitation of Intellectual Property, Blackstone Limited, London, 1990, page 16. Lihat juga Ranti Fauza Mayana, Perlindungan Desain Industri di Indonesia dalam Era Perdagangan Bebas, Grasindo, Jakarta, 2004, hlm., 41.
} 
Pihak lain dilarang melaksanakan hak DTLST tersebut tanpa persetujuan pemegang hak yang sah, kecuali pemakaian DTLST untuk kepentingan penelitian dan pendidikan sepanjang tidak merugikan kepentingan yang wajar dari pemegang hak DTLST. ${ }^{28}$ Pengaturan hak eksklusif ini dapat berakibat terhadap praktek monopoli (monopoli terbatas karena ada jangka waktu perlindungan), tetapi UU No. 5 Tahun 1999 mengecualikannya,29 untuk merangsang seseorang agar menghasilkan kreasi dan inovasi, tetapi untuk persaingan usaha tidak sehatnya tetap dilarang karena merupakan perbuatan melawan hukum (forbidden by the law and order); merugikan kepentingan pemegang hak dan kepentingan masyarakat (harms to right holder and public interest); mengurangi bahkan menghentikan penciptaan (reduce or stops the new work and inventions) yang berarti menghambat perkembangan industri (prevention for industrial development; dan simbol atau atribut kemerosotan moral (moral decline) atau itikad jahat (bad faith) pelaku usaha. ${ }^{30}$

Obyek perlindungan DTLST menurut UU No. 32 Tahun 2000 diberikan terhadap kreasi berupa rancangan teknologi elektronika yang erat kaitannya dengan sebuah bahan semikonduktor yang menghasilkan fungsi elektronik. Teknologi elektronika adalah bagian dari teknologi yang pada saat ini berkembang dengan pesat dan lazim disebut teknologi mutakhir karena pendorong utama untuk teknologi dalam kedua dekade terakhir, khususnya bagi industri komputer dan teknologi ${ }^{31}$ terkait lainnya. Apabila dispesifikkan menjadi teknologi

28 "kepentingan yang wajar" adalah penggunaan untuk kepentingan pendidikan dan penelitian itu secara umum tidak termasuk dalam penggunaan hak DTLST sebagaimana dimaksud dalam Ayat (1). Dalam bidang pendidikan, misalnya, kepentingan yang wajar dari Pendesain akan dirugikan apabila DTLST tersebut digunakan untuk seluruh lembaga pendidikan yang ada di kota tersebut. Kriteria kepentingan yang wajar tidak semata-mata diukur dari ada tidaknya unsur komersial, tetapi juga dari kuantitas penggunaan.

${ }^{29}$ Lihat Pasal 50 b UU No. 5 Tahun 1999 Tentang Larangan Praktek Monopoli dan Persaingan usaha tidak sehat.

${ }^{30}$ Lihat Abdulkadir Muhammad, Kajian Hukum Ekonomi Hak Kekayaan Intelektual, Citra Aditya Bakti, Bandung 2001, hlm., 317.

31 United Nation Conference on Transnational Corporation (UNCTC): teknologi dalam arti sempit dan arti luas. Dalam arti sempit teknologi adalah "technical knowledge or know-how that is knowledge related to the method and techniques of production of goods and service". Sedangkan dalam arti luas, teknologi meliputi barang-barang modal yaitu alat-alat, mesin-mesin, dan 
elektronika dalam kaitannya dengan perancangan DTLST, maka secara singkat dapat dijelaskan bahwa produk teknologi tersebut dilakukan dengan terlebih dahulu membuat desain (perencanaan produk), kemudian memproduksi (manufacture), dan perakitan (assembling).

Dalam kaitan dengan perlindungan hukum, kategori teknologi dapat dibedakan menjadi 2 (dua) bagian, yaitu teknologi yang mendapat perlindungan hukum (proprietary technology) dan teknologi yang tidak mendapat perlindungan hukum (non proprietary technology), yaitu teknologi yang sudah menjadi public domein dan tidak dimiliki oleh seseorang atau badan hukum tertentu. ${ }^{32}$ Hak yang mendapat perlindungan hukum di bidang DTLST harus memenuhi persyaratan, yaitu orisinal (asli) sebagaimana tercantum dalam Pasal 2 UU DTLST yang berbunyi:

(1) Hak DTLST diberikan untuk DTLST yang orisinal. ${ }^{33}$.

(2) DTLST dinyatakan orisinal apabila desain tersebut merupakan hasil karya mandiri Pendesain, dan pada saat DTLST tersebut dibuat tidak merupakan sesuatu yang umum bagi para Pendesain.

Ketentuan ini sejalan dengan Pasal 3 Ayat (2) Perjanjian Washington, ${ }^{34}$ perlindungan diterapkan pada DTLST terdiri dari kombinasi unsur-unsur dan interkoneksi yang umum, juga diberikan perlindungan, tetapi hanya bila kombinasi itu secara keseluruhan memenuhi persyaratan tentang orisinalitas.

seluruh sistem produksi yang dapat dikatakan sebagai teknologi berwujud. Lihat UNCTC, Transnational Corporation and Technology Transfer : Effect and Policy issues, New York, 1987, hlm 1. Lihat juga Dewi Astutty Mochtar, Perjanjian Lisensi Alih Teknologi dalam Pengembangan Teknologi Indonesia, Alumni, Bandung, 2001, hlm., 46. Sedangkan WIPO Licencing Guide for Developing Countries: "Technology means systematic knowledge for the manufacture of a product, the application of a process or rendering a service, whether that knowledge be reflected in an invention, an industrial design, a utility model or a new plat variety, or in technical information or skill, or in the services and the assistance of a industrial plant or the management of an industrial of commercial enterprise or its activities."

32 Richard D. Robinson, The International Transfer of Technology: Theory, Issues, Practices, Bal linger Publishing Company, Cambridge, Massachusetts, 1988, hlm., 4.

33 DTLST dinyatakan "orisinal" apabila Desain tersebut merupakan hasil karya Pendesain itu sendiri dan bukan merupakan tiruan dari hasil karya pendesain lain. Lihat Penjelasan Pasal Ayat (2) UU No 32 Tahun 2002.

34 "Protection shall apply to Lay out-Design that are original in the sense that they are the result of their creator' own intellectual effort and are not commonplace among creators of Lay out-Designs and manufacturers of Integrated Circuit at the time of their creation." 
Berdasarkan syarat pemberian Hak DTLST, maka perlindungan DTLST selaras dengan Hak Cipta yang mengharuskan adanya unsur "keaslian". Namun persyaratan yang mengatakan "pada saat DTLST tersebut dibuat tidak merupakan sesuatu yang umum bagi para Pendesain" sejalan dengan perlindungan yang diberikan oleh rezim paten. Dengan demikian, perlindungan terhadap DTLST menganut 2 (dua) pendekatan, yaitu Hak Cipta dan Paten.

Ketentuan Pasal 3 UU DTLST menjelaskan, tidak setiap DTLST yang orisinal dan baru tersebut dapat diberikan hak DTLST jika DTLST tersebut bertentangan dengan peraturan perundang-undangan yang berlaku, ketertiban umum, agama, atau kesusilaan (moral). Ketentuan ini mengandung arti bahwa hak DTLST akan diberikan apabila kepentingan umum tidak dilanggar, sehingga mempunyai fungsi sosial, dalam arti tidak hanya melindungi kepentingan pribadi pemiliknya tetapi juga memperhatikan kepentingan umum. Hal ini didasarkan atas suatu pemikiran bahwa hukum bukan kaidah berdiri sendiri karena merupakan kaidah heteronom (bukan otonom) yang tidak dapat terlepas dari kaidah sosial lainnya (terutama kaidah moral) karena itu perlu ada keserasian antara 2 (dua) kepentingan pribadi dan kepentigan umum.

Menurut Immanuel Kant, kaidah hukum bersifat heteronom mengandung arti bahwa yang memaksakan kehendaknya kepada manusia, yaitu kekuasaan masyarakat atau negara. ${ }^{35}$ Orang tunduk kepada hukum karena ada kekuasaan yang memaksa untuk taat tanpa syarat. Sedangkan kaidah yang bersifat otonom terdapat pada kaidah moral yang mengandung arti bahwa perintah moral berdasarkan kehendak seseorang terhadap dirinya sendiri, karena itu tiap-tiap orang harus menentukan menurut suara hatinya, apa yang dituntut moral terhadap dirinya sendiri, sehingga kaidah moral ditaati oleh manusia karena dorongan kehendak (kesadaran) diri sendiri. ${ }^{36}$ Dilihat dari sisi hubungannya,

\footnotetext{
35 Salman Luthan, Dialektika Hukum dan Moral dalam Perspektif Filsafat Hukum http://undana.ac.id/jsmallfib_top/JURNAL/HUKUM/HUKUM\%202011/fh-uii-no-4-vol-19-okt2013-salman\%20luthan.pdf. Diakses 22 Agustus 2016, pukul 20.00 WIB. 36 Id.
} 
fungsi hukum terhadap moral ada empat macam, yaitu: ${ }^{37}$ pertama, mentransformasikan kaidah moral yang bersifat individul menjadi kaidah hukum yang bersifat kolektif untuk mengatur masyarakat. Kedua, memperkuat kedudukan nilai-nilai, prinsip-prinsip, dan kaidah-kaidah moral dalam kehidupan personal dan sosial, khususnya nilai-nilai, prinsip-prinsip, dan kaidah-kaidah moral yang ditransformasikan menjadi kaidah hukum. Ketiga, hukum dapat membentuk moralitas baru dalam kehidupan masyarakat guna menciptakan ketertiban dalam interaksi sosial. Keempat, hukum melembagakan model pertanggungjawaban moral yang berlandaskan prinsip indeterminisme sebagai dasar pertanggungjawaban hukum.

Penulis berpendapat bahwa dari segi substantif, norma hukum tidak dapat dipisahkan dengan norma lainnya termasuk moral yang mengatur perilaku manusia, karena pemisahan tersebut akan mempunyai konsekuensi norma hukum hanya "aturan yang mati" yang mengatur perilaku manusia tetapi tidak sesuai dengan kondisi nyata di masyarakat. Namun dari sisi penegakan hukum, hal itu akan berjalan efektif apabila norma hukum dibersihkan dari anasir-anasir yang bersifat non yuridis sebagaimana "teori hukum murni" yang dikemukakan oleh Hans Kelsen.

Substansi Pasal 3 UU DTLST tersebut sudah sesuai dengan kondisi yang diperlukan untuk mewujudkan tujuan hukum "kegunaan atau kemanfaatan melalui prinsip 'keseimbangan' bagi 2 (dua) kepentingan (pribadi dan umum)”. Dengan demikian, apabila kreasi DTLST tersebut bertentangan dengan

\footnotetext{
${ }^{37}$ Id. Aliran Legal positivisme memandang perlu untuk memisahkan secara tegas antara hukum dan moral, hukum bercirikan rasionalistik, teknosentrik, dan universal, sehingga Dalam positivisme tidak ada hukum kecuali perintah penguasa, bahkan aliran positivis legalisme menganggap bahwa hukum identik dengan undang-undang. Secara umum legal positivisme melakukan kritik terhadap teori hukum kodrat yang mengutamakan kekuatan moral yang hidup sesuai dengan hukum yang tertulis dalam kodrat manusia, sementara legal positivisme tidak mempersoalkan kandungan subtantif yang normatif, etis maupun estetis, disamping itu juga mengajarkan bahwa hukum positif adalah norma-norma yudisial yang telah dibangun oleh otoritas negara. Lihat juga Ade Maman Suherman, Pengantar Perbandingan Sistem Hukum, Civil Law, Common Law, Hukum Islam, Cet 2, Raja Grafindo Persada, 2006, hlm 37, sebagaimana dikutip oleh http://rahmanamin1984. blogspot.co.id/2014/03/hukum-pidana.html. Diakses 24 Agustus 2016, pukul 22.00 WIB.
} 
kepentingan umum (dalam hal ini termasuk juga moral), hukum memberikan akibat, yaitu ditolaknya permohonan untuk pendaftaran, sehingga pendesain tidak mendapat jaminan perlindungan hukum terhadap perbuatan pihak lain berkaitan dengan penggunaan atau pemanfaatan DTLST yang dimilikinya.

Perlindungan terhadap Hak DTLST ${ }^{38}$ diberikan kepada pemegang hak sejak pertama kalinya desain tersebut dieksploitasi secara komersial dimanapun, atau sejak tanggal penerimaan dan paling lama 2 (dua) tahun terhitung sejak tanggal pertama kali dieksploitasi dalam arti dibuat, dijual, digunakan, dipakai atau diedarkan barang yang di dalamnya terdapat seluruh atau sebagian DTLST dalam kaitan transaksi yang mendatangkan keuntungan. Pemegang Hak DTLST ${ }^{39}$, yaitu pendesain atau penerima hak dari pendesain yang terdaftar dalam Daftar Umum DTLST. Selanjutnya jangka waktu perlindungan yang diberikan adalah selama 10 (sepuluh) tahun ${ }^{40}$ dan tanggal mulai berlakunya jangka waktu perlindungan hukum tersebut harus dicatat dalam Daftar Umum DTLST dan diumumkan dalam Berita Resmi DTLST. Jangka waktu perlindungan DTLST sesuai dengan Pasal 38 Ayat (1) Perjanjian TRIPs-WTO, sedangkan Pasal 8 Perjanjian Washington mengatakan perlindungan sekurang-kurangnya 8 tahun.

Ketentuan jangka waktu berkaitan dengan hak seorang pendesain atau pemegang DTLST, sehingga apabila jangka waktu tersebut telah terlampaui maka perlindungannya berakhir dan DTLST menjadi milik umum (public domain). Dengan demikian, hukum memberikan batasan bahwa kepemilikan DTLST tidak absolut karena dibatasi oleh lamanya jangka waktu yang diberikan sehingga "hak monopoli" secara mutlak dapat dihindarkan. Ketentuan ini untuk memberikan kesempatan kepada pihak lain yang beritikad baik dalam menggunakan hak DTLST tanpa harus meminta lisensi kepada pendesain atau pemegang DTLST karena telah menjadi milik umum, sehingga rasionya hukum menjamin "pemanfaatan hak" sebagaimana teori utility dikemukakan oleh Jeremy Bentham,

\footnotetext{
${ }^{38}$ Pasal 4 Ayat (1) dan (2) UU DTLST.

39 Pasal 1 butir 7 UU DTLST.

40 Pasal 4 Ayat (3) dan (4) UU DTLST.
} 
tetapi berbeda dengan pemikiran John Locke dan Hegel. Locke berpendapat bahwa seluruh pengetahuan (termasuk KI) bersumber dari pengalaman (empiris) manusia, sehingga menolak kaum rasionalis yang mengatakan sumber pengetahuan manusia yang terutama berasal dari rasio atau pikiran manusia. ${ }^{41}$ Sedangkan Hegel mengatakan bahwa pengetahuan (termasuk KI) tidak didasarkan rasio, tetapi pengalaman berdasarkan "dialektika", yaitu tesis, antithesis, dan sintesis.

Di sisi lain, jangka waktu perlindungan DTLST berkaitan dengan kepastian hukum atas kepemilikan hak tersebut, yaitu pemegang hak dapat melakukan tindakan hukum dalam lingkup jangka waktu yang telah ditentukan, sehingga siapapun termasuk pemerintah tidak dapat mengganggu hak DTLST. Sejalan dengan hal ini, Utrecht berpendapat "kepastian hukum mengandung dua pengertian; pertama, aturan yang bersifat umum sehingga individu mengetahui perbuatan yang boleh atau tidak boleh dilakukan. Kedua, keamanan hukum bagi individu dari kesewenangan pemerintah karena dengan adanya aturan yang bersifat umum itu individu dapat mengetahui apa yang boleh dilakukan negara terhadap individu". 42

\section{Perbandingan Desain Tata Letak Sirkuit Terpadu dengan Kekayaan Intelektual lainnya}

Untuk memahami perbedaan dan persamaan, analisis perbandingan interen terhadap DTLST dilakukan terhadap jenis KI lainnya, yaitu Hak Cipta dengan alasan KI ini menganut prinsip yang sama dengan DTLST, yaitu "originalitas", Paten karena memiliki obyek perlindungan yang sama, yaitu "teknologi", Desain Industri dengan alasan karena sama melindungi "desain", Rahasia Dagang karena mempunyai obyek perlindungan yang sama, yaitu "teknologi." Analisis perbandingan dilakukan terhadap substansi yang berkaitan

${ }^{41}$ Bandingkan dengan Franz Magnis-Suseno, Supra no 24.

42 Riduan Syahrani, Rangkuman Intisari Ilmu Hukum, Penerbit Citra Aditya Bakti, Bandung, 1999, hlm.23. 
dengan (1) pengaturan lingkup hak moral, (2) permohonan pendaftaran dengan hak prioritas, (3) kewajiban menjaga kerahasiaan, (4) upaya hukum terhadap permohonan yang ditolak oleh Ditjen, (5) perlindungan terhadap pemegang hak terdaftar yang beritikad baik apabila terjadi pembatalan, dan (6) penetapan sementara pengadilan.

Pengaturan lingkup Hak moral dalam DTLST diatur dalam Pasal 7 jo Pasal 24 UU. No. 32 Tahun 2000. Konsep hak moral berasal dari sistem hukum Eropa Kontinental, yaitu Perancis dan Jerman sejak abad ke-19.43 Dalam kaitan ini, J Thomas Mc Charty mengatakan bahwa pada dasarnya hak moral meliputi tiga kategori utama yaitu :44

(1). The right of attribution and paternity; the right of an author to receive credit as the uthor of work, to preven others from falsely being named author, and to prevent use of the author's name in connection with works the author did not create; (2). The right of integrity; the right of an author to preven multilation of a work; (3). The right of withdrawal, the right to widraw a work from distribution if it no linger represents the views of the author.

Ketentuan hak moral dalam DTLST terbatas hanya pada pencantuman nama Pendesain (the right of Paternity), sedangkan dalam Hak Cipta, pengaturan hak moralnya disebutkan secara tegas sebagaimana diatur dalam Bagian Pasal 5 s/d Pasal 7 UU No.28 Tahun 2014. Selanjutnya, hak moral dalam UU Hak Cipta pengaturannya lebih luas karena dapat dialihkan dengan wasiat atau sebab lain sesuai dengan ketentuan peraturan perundang-undangan setelah Pencipta meninggal dunia. ${ }^{45}$ Kemudian, khusus di bidang informasi elektronik tentang informasi manajemen, hak Pencipta dan/atau informasi elektronik Hak Cipta

\footnotetext{
${ }^{43}$ Sehubungan dengan itu, Paul Marret menjelaskan "On the Continent most countries have recognized for a very long time that the author of a book or other creative work has rights beyond his purely economic ones. These are principally the right to be recognised as author of his work and the right not to have it treated by his publisher, or anyone else, in a derogatory fashion. Such treatment might involve, for instance, abridging a book or altering it so that it misrepresents the author's ideas. In France, particularly there is an almost mystical regard for an author's moral rights." Lihat Supra no 27, hlm., 82.

${ }^{44}$ J Thomas Mc Charty page 281. Sebagaimana dikutip oleh Ranti Fauza Mayana, id., hlm., 14.

${ }^{45}$ Lihat Pasal 5 Ayat (2) UU No. 28 Tahun 2014.
} 
dilarang dihilangkan, diubah, atau dirusak. ${ }^{46}$ Pengaturan hak moral dalam UU No. 32 Tahun 2000 yang terbatas merupakan kelemahan UU tersebut karena tidak mencakup perubahan produk dan atau kreasi yang dilakukan oleh pihak lain (the right of integrity) secara tidak sah. Hal ini berakibat lebih jauh terhadap pengalihan hak dan lisensi yaitu mengubahnya tanpa izin dari pemegang hak. Selanjutnya, pihak lain yang tidak mempunyai hubungan hukum dengan pemegang hak, juga dapat mengubah produk dan atau kreasi tersebut tanpa dikategorikan sebagai pelanggaran hukum.

UU No. 32 Tahun 2000 menganut sistem konstitutif, artinya perlindungan diberikan apabila mendaftarkan, sehingga hak akan timbul apabila telah melakukan pendaftaran. Hal itu sebagaimana diatur dalam Pasal 9 s/d Pasal 22. Staniforth Ricketson mengatakan tujuan pendaftaran adalah "to give protection, through the grant of a monopoly right, to the visual from articles which are commercially mass produced." 47 Pentingnya pendaftaran DTLST ini berkaitan erat dengan permohonan dengan hak prioritas, ${ }^{48}$ agar perlindungan yang diberikan kepada pemegang hak luas lagi. Kelemahan UU No. 32 Tahun 2000 adalah tidak adanya ketentuan yang tegas tentang hak prioritas. Hal ini berbeda dengan ketentuan UU No. 13 Tahun 2016 Tentang Paten, dan UU No. 31 Tahun 2000 Tentang Desain Industri. Ketentuan tentang permohonan dengan Hak prioritas untuk Paten diatur didalam Pasal 30 s/d Pasal 32 UU No. 13 Tahun 2016, sedangkan di dalam Desain Industri terdapat dalam Pasal 16 dan Pasal 17 UU No. 31 Tahun 2000. Pengaturan tentang hak prioritas penting karena berkaitan dengan perlindungan secara internasional terhadap DTLST yang telah didaftarkan di luar negeri, namun belum didaftarkan di Indonesia. Permasalahan

46 Lihat Pasal 52 UU No. 28 Tahun 2014.

47 Staniforth Ricketson, page 45, sebagaimana dikutip oleh Ranti Fauza Mayana, Supra no 27, hlm., 20.

48 Hak Prioritas adalah hak Pemohon untuk mengajukan Permohonan yang berasal dari negara yang bergabung dalam Paris Convention for the Protection of Industrial Property atau Agreement Establishing the World Trade Organization untuk memperoleh pengakuan bahwa tanggal penerimaan di negara adalah merupakan tanggal prioritas di negara tujuan yang juga anggota salah sari dari kedua perjanjian itu selama pengajuan tersebut dilakukan dalam kurun waktu yang telah ditentukan berdasarkan Paris Convention tersebut. 
yang akan timbul adalah kemungkinan terjadinya pelanggaran hak DTLST oleh pihak yang tidak bertanggungjawab, yaitu mendaftarkan Hak DTLST yang bukan miliknya di Indonesia, padahal DTLST tersebut sudah didaftarkan oleh Pemilik hak yang sah di salah satu negara anggota peserta Konvensi Paris.

Ketentuan untuk menjaga kerahasiaan DTLST diatur dalam Pasal 18 dan Pasal 19 UU No. 32 Tahun 2000.49 Kelemahan UU No. 32 Tahun 2000 yang mengatur tentang kerahasiaan adalah tidak mengatur kewajiban menjaga kerahasiaan oleh kuasa atau konsultan Pendaftaran DTLST, padahal kuasa atau konsultan tersebut mengetahui dan memahami DTLST yang didaftarkan atas permintaan kliennya. Ketentuan tentang menjaga kerahasiaan merupakan hal yang penting, mengingat DTLST yang belum diumumkan tetap dapat dilindungi melalui ketentuan UU. 30 Tahun 2000 Tentang Rahasia Dagang. Kewajiban merahasiakan dalam UU DTLST hanya diberlakukan terhadap pegawai atau orang karena tugasnya bekerja untuk dan/atau atas nama Ditjen dilarang mengajukan Permohonan, memperoleh, memegang, atau memiliki hak yang berkaitan dengan DTLST, kecuali jika pemilikan tersebut diperoleh karena pewarisan terhitung tanggal Penerimaan. Diatur adanya kewajiban merahasiakan terhadap pegawai atau orang yang karena tugasnya bekerja untuk dan/atau atas nama Ditjen, hal yang sama dengan ketentuan dalam UU Desain Industri. ${ }^{50}$ Namun berbeda dengan UU Paten yang mengatur juga tentang Kerahasiaan oleh kuasa atau konsultan sebagaimana tercantum dalam Pasal 25 Ayat (3) UU Paten lama (UU No. 14 Tahun 2001)51, UU Paten baru (No. 13 Tahun 2016), tidak secara tegas mengatur hal tersebut, ketentuan Pasal 5 Ayat (1) UU tersebut mengatakan "Setiap Orang wajib menjaga kerahasiaan seluruh dokumen Permohonan."

Ditjen melakukan pemeriksaan kelengkapan persyaratan administratif terhadap permohonan sebagaimana dimaksud dalam Pasal 3, Pasal 10, dan Pasal

\footnotetext{
49 Lihat Pasal 18 dan Pasal 19 UU No. 32 Tahun 2000.

50 Pasal 22 dan Pasal 23 UU No. 31 Tahun 2000.

51 "Terhitung sejak tanggal penerimaan Kuasanya, Kuasa wajib menjaga kerahasiaan Invensi dan seluruh dokumen Permohonan sampai dengan tanggal diumumkannya Permohonan yang bersangkutan."
} 
11 UU No. 32 Tahun 2000. Namun UU No. 32 Tahun 2000 tidak mengatur apabila permohonan yang diajukan tersebut ditolak oleh Ditjen. Upaya hukum apa yang dapat dilakukan oleh pemohon tersebut. Hal ini berbeda dengan UU No. 31 Tahun 2000 Tentang Desain Industri yang menjelaskan bahwa apabila permohonannya ditolak oleh Ditjen dapat diajukan keberatan selama jangka waktu 30 hari terhitung sejak tanggal diterimanya surat penolakan, kemudian terhadap Keputusan penolakan atau penarikan kembali oleh Ditjen, Pemohon atau kuasanya dapat mengajukan gugatan melalui Pengadilan Niaga.

Ketentuan tentang pembatalan pendaftaran DTLST diatur dalam Pasal 29 s/d Pasal 36 UU. No. 32 Tahun 2000. Namun UU tersebut tidak mengatur perlindungan terhadap pemegang hak DTLST terdaftar yang beritikad baik untuk mendapatkan ganti rugi karena dibatalkan pendaftarannya oleh Pengadilan Niaga. Upaya hukum yang dilakukan oleh pemegang hak tersebut hanya dapat dimohonkan kasasi sebagaimana diatur dalam Pasal 32 UU No. 32 Tahun 2000.

UU No. 32 Tahun 2000 tidak mengatur tentang Penetapan Sementara pengadilan, padahal ketentuan tersebut penting untuk mencegah kemungkinan kerugian yang lebih besar pada pihak yang haknya dilanggar sehingga hakim Pengadilan Niaga diberi kewenangan untuk mengeluarkan penetapan sementara guna mencegah berlanjutnya pelanggaran dan masuknya barang yang diduga melanggar Hak DTLST ke jalur perdagangan, termasuk tindakan importasi serta untuk mencegah pihak pelanggar menghilangkan alat bukti. Hal ini berbeda dengan KI lainnya seperti UU No. 13 Tahun 2016 Tentang Paten yang mengatur tentang Penetapan sementara Pengadilan dalam Pasal 155 s/d Pasal 158, UU. No. 28 Tahun 2014 Tentang Hak Cipta dalam Pasal 106 s/d Pasal 109, dan UU No. 31 Tahun 2000 Tentang Desain Industri dalam Pasal 49 s/d Pasal 52. Ketiadaan ketentuan tentang penetapan sementara pengadilan di dalam UU No. 32 Tahun 2000 mengakibatkan pihak yang dirugikan berdasarkan bukti yang cukup, tidak dapat meminta kepada hakim pengadilan niaga untuk menerbitkan surat penetapan sementara tentang pencegahan masuknya produk yang berkaitan 
dengan pelanggaran hak DTLST dan penyimpanan bukti yang berkaitan dengan pelanggaran hak DTLST.

Peraturan Pelaksanaan dari UU No. 32 Tahun 2000 belum ada sehingga menyulitkan pelaksanaan terhadap pasal-pasal di dalam UU tersebut yang menjelaskan akan diatur lebih lanjut, seperti ketentuan tentang tata cara permohonan pendaftaran DTLST sebagaimana diatur dalam Pasal 9 sampai dengan Pasal 10 UU No. 32 Tahun 2000, Pasal 13 UU yang mengatur mengenai syarat-syarat untuk diangkat sebagai konsultan DTLST dan tata cara pengangkatannya, Pasal 22 mengatur tentang ketentuan mengenai syarat dan tata cara pemberian Sertifikat DTLST, Pasal 28 mengenai perjanjian lisensi DTLST, Pasal 37 tentang persyaratan, jangka waktu, dan tata cara pembayaran biaya permohonan, permintaan petikan Daftar Umum, permintaan salinan Sertifikat, pencatatan pengalihan Hak DTLST, dan pencatatan perjanjian lisensi. Namun, ketidaklengkapan Peraturan Pelaksana untuk melaksanakan seluruh norma yang ada dalam substansi UU terkait yang mengamanatkan akan diatur lebih lanjut berlaku untuk hampir semua jenis KI lainnya.

Sejalan dengan perkembangan teknologi mutakhir (elektronika) sebagai dasar bagi pengembangan teknologi informatika seperti komputer, IC (intergrated Circuit) tidak dapat dilindungi melalui UU Tentang Paten karena perlindungan terhadap teknologi dalam rezim hukum paten bersifat umum. Selanjutnya, kreasi dan inovasi dalam bentuk desain juga mendapat perlindungan hukum melalui Desain Industri, tetapi desain tersebut berkaitan kesan estetis (seni) bukan teknologi mutakhir, sebagaimana tercantum dalam Pasal 1 huruf Angka 1 UU No. 31 Tahun 2000 Tentang Desain Industri. ${ }^{52}$

52 "Desain Industri adalah suatu kreasi tentang bentuk, konfigurasi, atau komposisi garis atau warna, atau garis dan warna, atau gabungan daripadanya yang berbentuk tiga dimensi atau dua dimensi yang memberikan kesan estetis dan dapat diwujudkan dalam pola tiga dimensi atau dua dimensi serta dapat dipakai untuk menghasilkan suatu produk, barang, komoditas industri, atau kerajinan tangan." 
Berdasarkan hal itu, tujuan UU No. 32 Tahun 2000 untuk mengantisipasi perkembangan teknologi mutakhir sebagai dasar dalam teknologi informatika tidak dapat dijangkau melalui UU Paten atau UU Desain Industri. Teknologi informatika yang menggunakan IC pada saat ini memegang peranan penting dalam segala aspek kehidupan karena proses dapat lebif efektif dan efisien. Dengan demikian lahirnya UU No. 32 Tahun 2000 merupakan solusi perlindungan dalam mengantisipasi perkembangan teknologi mutakhir sekaligus mendorong para kreator atau inovator teknologi tersebut karena sudah ada payung hukumnya, sebagaimana teori hukum pembangunan yang dikemukakan oleh Mochtar Kusumaatmadja "bahwa hukum berada di depan yang berfungsi sebagai sarana perubahan sosial masyarakat, dalam arti hukum mengarahkan perkembangan teknologi agar dapat berjalan dengan tertib.

\section{Penutup}

Berdasarkan analisis perbandingan interen terhadap DTLST jenis KI lainnya terdapat perbedaan dan persamaan. Ketentuan UU yang mengatur jenis KI tersebut (UU No. 32 Tahun 2000) masih memiliki kelemahan yang bersifat substantif berkaitan dengan hak moral dibandingkan Hak Cipta, hak prioritas dibandingkan dengan Paten dan Desain Industri, dan Penetapan Sementara dibandingkan Hak Cipta, Paten dan Desain Industri. Adapun persamaan umum yang terdapat pada semua jenis kekayaan intelektual, yaitu belum adanya Peraturan Pelaksanaan yang lengkap sebagaimana diamanatkan oleh kekayaan intelektual yang bersangkutan. Namun demikian, lahirnya UU DTLST paling tidak merupakan payung hukum dalam melindungi kreasi sebagai akibat perkembangan teknologi mutakhir di bidang elektronika yang pada saat ini semakin pesat dan tidak dapat dilindungi rezim hukum KI lainnya. Oleh karena itu dari segi normatif, agar kelemahan substansi UU No. 32 Tahun 2000 tersebut diantisipasi perlu melakukan perubahan dan melengkapi Peraturan Pelaksana yang diamanatkan oleh UU DTLST sehingga dapat mendukung sepenuhnya 
perkembangan teknologi mutakhir dan menjamin tujuan hukum yaitu kepastian hukum, keadilan dan kemanfaatan.

\section{Daftar Pustaka}

\section{Buku:}

Ade Maman Suherman, Pengantar Perbandingan Sistem Hukum, Civil Law, Common Law, Hukum Islam, Cet 2, Raja Grafindo Persada, 2006.

Abdulkadir Muhammad, Kajian Hukum Ekonomi Hak Kekayaan Intelektual, Citra Aditya Bakti, Bandung 2001.

Dewi Astutty Mochtar, Perjanjian Lisensi Alih Teknologi dalam Pengembangan Teknologi Indonesia, Alumni, Bandung, 2001.

Badan Pembinaan Hukum Nasional - Depkeh RI, Naskah Akademis Peraturan Perundang-undangan tentang RUU Perlindungan Integrated Circuits, 19941995.

Franz Magnis-Suseno, Filsafat sebagai Ilmu Kritis, Penerbit Kanisius, Yogyakarta, 1992.

Hilary Pearson, dan Clifford Miller, Commercial Exploitation of Intellectual Property, Blackstone Limited, London, 1990.

Paingot Rambe Manalu, Hukum Dagang International, Pengaruh Globalisasi Ekonomi Terhadap Hukum Nasional, khususnya Hukum Hak Atas Kekayaan Intelektual, CV Novindo Pustaka Mandiri, Jakarta, 2000.

Paul Marett, Intellectual Property Law, Sweet \&Maxwell, London, 1996.

Rachmadi Usman, Hukum Hak atas Kekayaan Intelektual : Perlindungan dan Dimensi Hukumnya di Indonesia, Alumni, Bandung, 2003.

Ranti Fauza Mayana, Perlindungan Desain Industri di Indonesia dalam Era Perdagangan Bebas, Grasindo, Jakarta, 2004.

Richard D. Robinson, The International Transfer of Technology: Theory, Issues, Practices, Bal linger Publishing Company, Cambridge, Massachusetts, 1988.

Riduan Syahrani, Rangkuman Intisari Ilmu Hukum, Penerbit Citra Aditya Bakti, Bandung, 1999.

Sudargo Gautama dan Rizawanto Winata, Umdang-Undang Desain Tata Letak Sirkuit Terpadu, Citra Aditya Bakti, Bandung, 2002.

Soerjono Soekanto, Sosiologi Suatu Pengantar, PT RajaGrafindo Persada, Jakarta, 1998.

Soerjono Soekanto dan Sri Mamudji, Penelitian Hukum Normatif : Suatu Tinjauan Singkat, Jakarta, PT RajaGrafindo Persada, 2004.

Staniforth Ricketson, The Law Intellectual Property, Australia, 1991.

Tomas Mc Charty, Mc charty's Desk Encyclopedia of Intellectual Property in Australia, Second Edition, Butterworths, Sidney, 1997. 


\section{Perundang-undangan:}

Kitab Undang-Undang Hukum Perdata.

Republik Indonesia, Undang-Undang Nomor 5 Tahun 1999 Tentang Larangan Praktek Monopoli dan Persaingan usaha tidak sehat.

Republik Indonesia, Undang-Undang Nomor 31 Tahun 2000 Tentang Desain Industri.

Republik Indonesia, Undang-Undang Nomor 32 Tahun 2000 Tentang Desain Tata Letak Sirkuit Terpadu.

Republik Indonesia, Undang-Undang Nomor.28 Tahun 2014 Tentang Hak Cipta. Republik Indonesia, Undang-Undang Nomor 13 Tahun 2016 Tentang Paten.

\section{Perjanjian/Konvensi Internasional:}

Treaty on Intellectual Property in Respect of Integrated Circuits.

UNCTC, Transnational Corporation and Technology Transfer : Effect and Policy issues, New York, 1987.

WIPO Licencing Guide for Developing Countries, Geneva, 1977.

\section{Sumber lainnya:}

http://elearning.upnjatim.ac.id/courses/HKB7024ff34/ document/ pengenalan perbandingan_hu-kum.pptx?cidReq=HKB702429e2. Diakses 15 Agustus 2016, pukul 21.00 WIB.

https://id.wikipedia.org/wiki/John_Locke. Diakses 25 November 2016, pukul 20.00 WIB.

https://id.wikipedia.org/wiki/Georg_Wilhelm_Friedrich_Hegel. Diakses 15 Desember 2016, pukul 21.00 WIB.

http://rahmanamin1984. blogspot.co.id/2014/03/ hukum-pidana.html. Diakses 24 Agustus 2016, pukul 22.00 WIB.

Salman Luthan, Dialektika Hukum dan Moral dalam Perspektif Filsafat Hukum http://undana.ac.id/jsmallfib_top/JURNAL/HUKUM/HUKUM\%202011/fhuii-no-4-vol-19-okt-2013-salman\%20luthan.pdf. Diakses 22 Agustus 2016, pukul 20.00 WIB.

Van Apeldoorn, sebagaimana dikutip oleh Sudikno dalam, http://sudiknoartikel. blogspot.co.id/2012/04/perbandingan-hukum.html. Diakses 18 Agustus 2016, pukul 22.00 WIB. 